\title{
Prey consumed by Guiana dolphin Sotalia guianensis (Cetacea, Delphinidae) and franciscana dolphin Pontoporia blainvillei (Cetacea, Pontoporiidae) in an estuarine environment in southern Brazil
}

\author{
Marta J. Cremer ${ }^{1}$, Pedro C. Pinheiro ${ }^{1} \&$ Paulo C. Simões-Lopes ${ }^{2}$ \\ 1. Laboratório de Nectologia, Departamento de Ciências Biológicas, Universidade da Região de Joinville, Caixa Postal 110, 89240-000, São Francisco do Sul, SC, Brasil (marta.cremer@univille.br) \\ 2. Laboratório de Mamíferos Aquáticos, Departamento de Ecologia e Zoologia, Universidade Federal de Santa Catarina, Caixa Postal 5102, 88040-970, Florianópolis, SC, Brasil
}

\begin{abstract}
The present study provides information about the diet of sympatric populations of small cetaceans in the Babitonga Bay estuary This is the first study on the diet of these species in direct sympatry. The stomach contents of seven Guiana dolphins Sotalia guianensis and eight franciscanas Pontoporia blainvillei were analyzed. The prey of both cetaceans was mostly teleost fishes, followed by cephalopods. We identified 13 teleost fishes as part of the diet of the franciscanas, and 20 as part of the diet of Guiana dolphins. Lolliguncula brevis was the only cephalopod recorded, and was the most important prey for both cetaceans. Stellifer rastrifer and Gobionellus oceanicus were also important for franciscana, so as Mugil curema and Micropogonias furnieri were important for Guiana dolphins. Stellifer rastrifer and Cetengraulis edentulus were the fishes with the highest frequency of occurrence for franciscana (50\%), while Achirus lineatus, C. edentulus, S. brasiliensis, Cynoscion leiarchus, M. furnieri, M. curema, Diapterus rhombeus, Eugerres brasilianus and G. oceanicus showed $28.6 \%$ of frequency of occurrence for Guiana dolphins. Franciscanas captured greater cephalopods than the Guiana dolphins in both total length $(z=-3.38 ; n=40 ; p<0.05)$ and biomass $(z=-2.46 ; n$ $=40 ; \mathrm{p}<0.05)$. All of the prey species identified occur inside the estuary, which represents a safe habitat against predators and food availability, reinforcing the importance of the Babitonga Bay for these cetacean populations.
\end{abstract}

KEYWORDS. Diet, Babitonga Bay, cetacean, fish, cephalopod.

RESUMO. Presas consumidas pelo boto-cinza Sotalia guianensis (Cetacea, Delphinidae) e pela toninha Pontoporia blainvillei (Cetacea, Pontoporiidae) em ambiente estuarino no sul do Brasil. O presente estudo fornece informações sobre a dieta de populações simpátricas de pequenos cetáceos no estuário da Baía da Babitonga. Este é o primeiro estudo sobre a dieta destas espécies em simpatria direta. Foi analisado o conteúdo estomacal de sete botos-cinza Sotalia guianensis e oito toninhas Pontoporia blainvillei. As presas de ambos cetáceos foram principalmente peixes teleósteos, seguida de cefalópodes. Foram identificadas 13 espécies de peixes teleósteos como parte da dieta de toninhas e 20 como parte da dieta de botos-cinza. Lolliguncula brevis foi o único cefalópode registrado e foi a presa mais importante para ambos cetáceos. Stellifer rastrifer e Gobionellus oceanicus foram também importantes para a toninha, assim como Mugil curema e Micropogonias furnieri foram importantes para os botos-cinza. Stellifer rastrifer e Cetengraulis edentulus foram as espécies de peixes com maior frequencia de ocorrência para a toninha (50\%), enquanto Achirus lineatus, C. edentulus, S. brasiliensis, Cynoscion leiarchus, M. furnieri, M. curema, Diapterus rhombeus, Eugerres brasilianus e G. oceanicus apresentaram 28,6 \% de frequência de ocorrência para os botos-cinza. As toninhas capturaram cefalópodes maiores do que os botos-cinza, tanto em comprimento total $(z=-3,38 ; n=40 ; p<0,05)$ como em biomassa $(z=-2,46 ; n=40 ; p<0,05)$. Todas as espécies de presas identificadas ocorrem no interior do estuário, que representa um habitat seguro contra a ação de predadores com disponibilidade de presas, reforçando a importância da Baía da Babitonga para estas populações de cetáceos.

PALAVRAS-CHAVE. Dieta, Baía da Babitonga, cetáceos, peixes, cefalópodes.

Information regarding feeding habits is important for understanding the trophic relationships in an ecosystem. Small cetaceans are top predators and have an important influence on the populations of their prey species and, consequently, on the energy flow in their associated ecosystems (Bowen \& SinIFF, 1999).

The Guiana dolphin, Sotalia guianensis (P. J. van Bénéden, 1864), is a coastal species distributed from Nicaragua (CARR \& BONDE, 2000) to state of Santa Catarina, southern Brazil (SIMÕEs-Lopes, 1988). The franciscana, Pontoporia blainvillei (Gervais \& D'Orbigny, 1844), can be found from the north of state of Espírito Santo, south-eastern Brazil (Siciliano, 1994) to Golfo Nuevo, northern Argentina (CRESPo et al., 1998). In contrast to the Guiana dolphin, the franciscana does not commonly occur in estuarine areas, with the exception of Babitonga Bay in south Brazil (CREMER \& SimÕEs-Lopes, 2005). In this area, both dolphins live in direct sympatry (sensu BEARZI, 2005), but they were never seen together (CRemer \& Simões-Lopes, 2008). The franciscana population is smaller than the Guiana dolphin population in this area, being estimated at 50 and 208 individuals, respectively (CREMER \& SimõesLopes, 2008; Cremer et al., 2011). According to Pauly et al. (1998), franciscana and Guiana dolphin exhibit a very similar trophic level.

Franciscana feeding habits have been extensively studied, mainly in its southern distribution range. Published data about its diet was described in some areas of Argentina and Uruguay (FITCH \& BRownell, 1971; Rodríguez et al., 2002), as well as for the Brazilian coast (SANTOS \& HaImovicI, 2001; BitTAR \& DI BENEDITTO, 2009). A review of prey species recorded for the franciscana can be found at DANILEWICZ et al. (2002). The species feeds mainly on teleost fishes. Cephalopods were also found to be very important in its diet, and crustaceans were poorly represented.

Studies related to Guiana dolphins diet have been intensified during recent years in Brazil (Borobia \& Barros, 1989; SANTOS \& Haimovici, 2001; SAntos et al., 2002; Gurjão et al., 2003; Di Beneditto \& Siciliano, 2007; PANSARD et al., 2010; DaURA-Jorge et al., 2011). Teleost fishes were also considered the main prey items, though the diet includes cephalopods and crustaceans. 
Studies related to cetacean feeding ecology are traditionally conducted through the analyses and interpretation of stomach contents that are resistant to digestion, such as fish teeth, bone structures, scales, squid beaks, crustacean exoskeleton fragments, and otoliths of fishes (Fitch \& Brownell, 1968; Pierce \& Boyle, 1991; Bowen \& SinifF, 1999). However, digestion and the presence of structures that originated from the prey species stomachs can result in distortion of the results (Fitch \& Brownell, 1971). The fact that the majority of such results have been derived from the examination of stomach contents of stranded animals may also be a reason for errors (BARRos \& ODELL, 1990). However, such method was considered a reasonable approach for dolphins like Tursiops truncatus (Montagu, 1821) (BARRos \& Wells, 1998).

Almost all the studies addressing the diet of franciscana and Guiana dolphins revealed that the composition of prey differed along the distribution and habitats occupied by these species. The main objective of the present study was to provide additional data on the diet of franciscana and Guiana dolphins, so as to identify the preys consumed by both cetacean species in Babitonga Bay, an estuarine environment in south Brazil. This information could be very useful to understand the ecology of these populations, which occur in direct sympatry in this estuary.

\section{MATERIALS AND METHODS}

Sample collection. The samples used in this study were obtained from dead animals recovered inside Babitonga Bay estuary, on north coast of state of Santa
Catarina, south Brazil $\left(26^{\circ} 02^{\prime}-26^{\circ} 28^{\prime} \mathrm{S}\right.$ and $48^{\circ} 28^{\prime}$ $\left.48^{\circ} 50^{\prime} \mathrm{W}\right)$. Thus, we presumed that they corresponded to animals that were part of the recognised populations of the Guiana dolphins and franciscanas that live in this estuary (Cremer \& Simões-Lopes, 2008; Cremer et al., 2011). The collection of the animals was opportunistic and depended on the information of local people. The results do not reflect the seasonal stranding patterns of cetaceans in the study area. All of the animals recovered were recorded in the collection of UNIVILLE (Universidade da Região de Joinville).

We analysed the stomach contents of eight franciscanas and seven Guiana dolphins, collected between 2000 and 2006. Details about the studied specimens are presented in Table I. Each animal was measured and the sex determined whenever possible. During necropsy the stomachs, including all chambers, were excised and frozen for later analysis.

Data analysis. Stomach contents were washed through three sieves, with 2-mm, $850-\mu \mathrm{m}$ and $425-\mu \mathrm{m}$ mesh sizes. Food items were recovered, and information about the prey species was obtained through the analysis of fish otoliths and cephalopod beaks present in the stomach. The identification of shrimps was not possible because of the digestion stage. Otoliths and cephalopod beaks were stored dry, and undigested items were preserved in $70 \%$ alcohol. The number of prey items found in each stomach is presented in Table I.

Teleost fish otoliths were identified through reference collections of the Laboratório de Nectologia, Universidade da Região de Joinville, and also through the use of specific identification keys (CORRÊA \& VIANNA, 1992; Lemos et al., 1992; Lemos et al., 1995a,b). We used the sagitta otolith

Tab. I. Information about sex, total length (TL), date of recovery and number of prey items found in the stomachs of eight Pontoporia blainvillei and seven Sotalia guianensis individuals recovered for analysis in Babitonga Bay, southern Brazil (ni = sex not identified; 1, female with a foetus of $37 \mathrm{~cm}$ length; SD, standard deviation; M, male; F, female).

\begin{tabular}{|c|c|c|c|c|c|c|}
\hline Number & Sex & TL (cm) & Date & Otoliths & Beaks & Shrimps \\
\hline \multicolumn{7}{|l|}{ P. blainvillei } \\
\hline UNIVILLE - $10^{1}$ & $\mathrm{~F}$ & 138 & $16 / 07 / 2001$ & & 13 & \\
\hline UNIVILLE - 15 & $\mathrm{~F}$ & 95.2 & $15 / 08 / 2001$ & 9 & 2 & \\
\hline UNIVILLE - 37 & ni & 118 & $08 / 09 / 2002$ & 35 & & 1 \\
\hline UNIVILLE - 42 & ni & 107 & $05 / 08 / 2003$ & 81 & & \\
\hline UNIVILLE - 44 & ni & 73 & $13 / 01 / 2006$ & 59 & 1 & \\
\hline UNIVILLE - 53 & M & 87.3 & $15 / 08 / 2005$ & 316 & & \\
\hline UNIVILLE - 56 & M & 109 & $23 / 06 / 2006$ & 34 & 8 & \\
\hline UNIVILLE - 62 & M & 111 & $13 / 09 / 2006$ & 8 & 8 & \\
\hline Mean $\pm \mathrm{SD}$ & \multicolumn{3}{|c|}{$98.8 \pm 32.5 \mathrm{~cm}$} & & & \\
\hline \multicolumn{7}{|l|}{ S. guianensis } \\
\hline UNIVILLE - 06 & M & 148 & $29 / 11 / 2000$ & 23 & & 1 \\
\hline UNIVILLE - 16 & M & 198 & $17 / 09 / 2001$ & 30 & & \\
\hline UNIVILLE - 31 & $\mathrm{~F}$ & 145 & $28 / 03 / 2004$ & & & \\
\hline UNIVILLE - 33 & M & 168 & $27 / 10 / 2002$ & 31 & & 2 \\
\hline UNIVILLE - 34 & M & 135 & $14 / 02 / 2003$ & & 7 & \\
\hline UNIVILLE - 40 & M & 159 & $21 / 12 / 2005$ & 13 & & \\
\hline UNIVILLE - 52 & M & 167 & $25 / 04 / 2006$ & 27 & 1 & \\
\hline Mean \pm SD & \multicolumn{3}{|c|}{$160 \pm 20.6 \mathrm{~cm}$} & & & \\
\hline
\end{tabular}


for species identification, preferentially the left one. Teleost fish otoliths were measured to estimate the total length of the fish based on regression equations presented by CorrêA \& Vianna (1992), Lemos et al. (1992; 1995a,b) and from data of the reference collections of the Laboratorio de Nectologia, Universidade da Região de Joinville. Measurements were collected using a micrometric scale (0.01-mm precision) adapted to a stereoscopic microscope. Imagines were taken using Image Pro Plus 3.0 software adapted to a stereoscopic microscope.

Cephalopod beaks were identified with the help of the reference collection of cephalopods of the Centro de Pesquisa e Gestão de Recursos Pesqueiros do Litoral Sudeste e Sul, Instituto Chico Mendes de Conservação da Biodiversidade (CEPSUL/ ICMBio, Itajaí, SC). For the estimation of mantle length and total weight, measurements of lower rostral length and upper rostral length were used. All measurements were collected using a stereoscopic microscope. The total length and weight were estimated based on regression equations presented by SANTOS \& HaImovici (2001).

The total length of the prey ingested by the dolphins was compared using the Mann-Whitney U-test (Statistica $6.0^{\circledR}$ ) (only for those species with sufficient sample size). The significance level considered was $\alpha<0.05$. We calculated the percentage numeric frequency $(\% \mathrm{NF})$ and the percentage of frequency of occurrence (\%FO). We used an adaptation to the PINKAS et al. (1971) index of relative importance (IRI) because of the high number of digested otoliths for which we could not estimate the biomass. The index was calculated as: IRI = $\% \mathrm{NF} x \% \mathrm{FO}$. For each stomach, the maximum number of either left or right otoliths was used as the minimum number of identified fishes. The same was assumed for the lower and upper cephalopod beaks.

\section{RESULTS}

We recovered a total of 852 otoliths; $19.5 \%$ were found in Guiana dolphin stomachs and $80.5 \%$ in franciscana stomachs. Cephalopod beaks were the second most important item found, with a total of 71 beaks $(20 \%$ in Guiana dolphin stomachs and $80 \%$ in franciscana stomachs) (Tab. I). Crustaceans were poorly represented, with only three individuals registered in Guiana dolphin stomachs and one in a franciscana stomach. We identified 478 otoliths $(56.1 \%)$ and 40 cephalopod beaks $(56.3 \%)$. The shrimp species could not be identified because they were highly digested, which was also true for 374 otoliths $(43.9 \%)$. Only one stomach (S. guianensis) was empty (UNIVILLE 31). To avoid errors, the size and biomass of many teleost species was not estimated because they were highly digested.

Teleost fishes were the principal prey identified in the diet of both cetacean species, and the family Sciaenidae was the most common. However, two franciscana stomachs and one Guiana dolphin stomach contained only cephalopods. Twenty-six fish species were identified, 13 of which were observed as franciscana prey items and 20 as Guiana dolphin prey items (Tabs II, III). Seven fish species and the cephalopod Lolliguncula brevis (de Blainville, 1823) were consumed by both cetaceans. Thus, the Guiana dolphin was observed to prey on more species $(21$ species) than the franciscana (14 species), and $50 \%$ of the franciscana prey species were also found in the diet of the Guiana dolphin. For the Guiana dolphin, only $33.3 \%$ of the prey species were shared with franciscana.

The highest frequency of occurrence $(\% \mathrm{FO})$ for the franciscana prey was observed for the cephalopod

Tab. II. Prey consumed by franciscana Pontoporia blainvillei in Babitonga Bay, southern Brazil, with respective values of the number of individuals $(\mathrm{N})$, frequency of occurrence (FO), numeric frequency (NF), index of relative importance (IRI) and importance level (IL) of each prey species ( $\square=$ species shared with Sotalia guianensis); (IL value was established according to the value of IRI: the highest value of IRI was also the highest value of IL).

\begin{tabular}{|c|c|c|c|c|c|c|}
\hline Family & Species & $\mathrm{N}$ & FO (\%) & NF (\%) & IRI & IL \\
\hline \multicolumn{7}{|l|}{ TELEOST } \\
\hline Paralichthidae & Paralichthys isosceles & 2 & 12.5 & 0.4 & 5 & 11 \\
\hline \multirow[t]{3}{*}{ Engraulidae } & Cetengraulis edentulus & 28 & 50 & 5.3 & 265 & 3 \\
\hline & Anchoa filifera & 6 & 37.5 & 1.1 & 41.2 & 7 \\
\hline & Lycengraulis grossidens & 9 & 25 & 1.7 & 42.5 & 6 \\
\hline \multirow[t]{6}{*}{ Sciaenidae } & Stellifer brasiliensis & 20 & 37.5 & 3.8 & 142.5 & 4 \\
\hline & Stellifer rastrifer & 119 & 50 & 22.7 & 1.135 & 1 \\
\hline & Cynoscion leiarchus & 4 & 12.5 & 0.8 & 10 & 10 \\
\hline & Cynoscion microlepidotus & 2 & 12.5 & 0.4 & 1 & 12 \\
\hline & Micropogonias furnieri & 2 & 12.5 & 0.4 & 5 & 8 \\
\hline & Isopisthus parvipinnis & 8 & 37.5 & 0.8 & 30 & 11 \\
\hline Gerreidae & Eugerres brasilianus & 5 & 12.5 & 0.9 & 11.2 & 9 \\
\hline Clupeidae & Opisthonema oglinum & 12 & 25 & 2.3 & 57.5 & 5 \\
\hline Gobiidae & Gobionellus oceanicus & 147 & 25 & 28.1 & 702.5 & 2 \\
\hline Non identified & - & 374 & - & - & - & - \\
\hline \multicolumn{7}{|l|}{ CEPHALOPODS } \\
\hline Loliginidae & Lolliguncula brevis & 32 & 62.5 & 100 & 6,250 & 1 \\
\hline
\end{tabular}


specie, L. brevis $(62.5 \%)$ and for two fish species: Cetengraulis edentulus (Cuvier, 1829) (Engraulidae) and Stellifer rastrifer (Jordan, 1899) (Sciaenidae), which were found in $50 \%$ of the stomachs investigated (Tab. II). Stellifer rastrifer also corresponded to the species with highest IRI, followed by Gobionellus oceanicus (Pallas, 1770) (Gobiidae). The IRI value of these species was much higher than that of the other species.

Lolliguncula brevis occurred in $100 \%$ of the Guiana dolphins analyzed, followed by nine fish species with $28.6 \%$ of frequency of occurrence: Achirus lineatus (Linnaeus, 1758) (Achiridae), C. edentulus (Engraulidae), Stellifer brasiliensis (Schultz, 1945), Cynoscion leiarchus (Cuvier, 1830), Micropogonias furnieri (Desmarest, 1823) (Sciaenidae), Mugil curema (Valenciennes, 1836) (Mugilidae), Diapterus rhombeus (Cuvier, 1829), Eugerres brasilianus (Cuvier, 1830) (Gerreidae) and G. oceanicus (Tab. III). Although the IRI value declined gradually between the prey items, the highest value was recorded for M. curema, followed by M. furnieri.

The sizes of the cephalopods consumed by both cetaceans differed in both total length and biomass. Franciscanas captured greater cephalopods than the Guiana dolphins in both total length $(z=-3.38 ; n=40 ; p<$ $0.05)$ and biomass $(\mathrm{z}=-2.46 ; \mathrm{n}=40 ; \mathrm{p}<0.05)$ (Tab. IV).

We did not observe differences in the sizes of either $S$. brasiliensis $(\mathrm{z}=1.53 ; \mathrm{n}=26 ; \mathrm{p}>0.05)$ or $C$. edentulus ( $\mathrm{z}=1.13 ; \mathrm{n}=26 ; \mathrm{p}>0.05)$ (Tab. IV) individuals consumed by both cetaceans. For the other prey species shared between the franciscana and Guiana dolphins, we could not analyse the differences because of the small sample size. Only two $M$. furnieri individuals were recorded in franciscana stomachs, with an average total length estimated at $4.1 \pm 0.05 \mathrm{~cm}$. This value was much lower than that estimated for the individuals consumed by the Guiana dolphin $(10.4 \pm 3 \mathrm{~cm})$. The same tendency was observed for Anchoa filifera (Fowler, 1915) because Guiana dolphins seem to consume larger individuals than did franciscanas.

\section{DISCUSSION}

BARRos \& Odell (1990) pointed out that findings derived from stranded animals may be a reason for errors in such results. However, the animals analysed in this study do not exhibit signs of disease or trauma and probably died as a consequence of entanglement in fishing nets, which is a problem previously described in Babitonga Bay by PinHeiro \& CREMER (2003).

We analysed only the stomachs from animals recovered inside Babitonga Bay, where the populations of these two cetaceans are small, estimated at 50 individuals for franciscanas (CREMER \& SiMÕes-LoPES, 2008 ) and 208 individuals for Guiana dolphins (CREMER et al., 2011). In this way, we considered that our aim

Tab. III. Prey consumed by Guiana dolphin Sotalia guianensis in Babitonga Bay, southern Brazil, with respective values of the number of individuals $(\mathrm{N})$, frequency of occurrence (FO), numeric frequency (NF), index of relative importance (IRI) and importance level (IL) of each prey ( $\square=$ species shared with Pontoporia blainvillei); (IL value was established according to the value of IRI: the highest value of IRI was also the highest value of IL).

\begin{tabular}{|c|c|c|c|c|c|c|}
\hline Family & Species & $\mathrm{N}$ & FO $(\%)$ & $\mathrm{NF}(\%)$ & IRI & $\mathrm{IL}$ \\
\hline \multicolumn{7}{|l|}{ TELEOST } \\
\hline Achiridae & Achirus lineatus & 2 & 28.6 & 1.7 & 48.6 & 9 \\
\hline \multirow[t]{2}{*}{ Paralichthidae } & Citharichthys spilopterus & 8 & 14.3 & 6.7 & 95.8 & 7 \\
\hline & Citharichthys arenaceus & 1 & 14.3 & 0.8 & 11.4 & 12 \\
\hline Cynoglossidae & Symphurus tesselatus & 1 & 14.3 & 0.8 & 11.4 & 12 \\
\hline \multirow[t]{2}{*}{ Engraulidae } & Cetengraulis edentulus & 6 & 28.6 & 5 & 143 & 5 \\
\hline & Anchoa filifera & 1 & 14.3 & 0.8 & 11.4 & 12 \\
\hline \multirow[t]{6}{*}{ Sciaenidae } & Larimus breviceps & 1 & 14.3 & 0.8 & 11.4 & 12 \\
\hline & Stellifer brasiliensis & 7 & 28.6 & 5.9 & 168.7 & 4 \\
\hline & Cynoscion acoupa & 2 & 14.3 & 1.7 & 24.3 & 11 \\
\hline & Cynoscion leiarchus & 2 & 28.6 & 1.7 & 48.6 & 9 \\
\hline & Conodon nobilis & 1 & 14.3 & 0.8 & 11.4 & 12 \\
\hline & Micropogonias furnieri & 14 & 28.6 & 11.8 & 337.5 & 2 \\
\hline \multirow[t]{3}{*}{ Mugilidae } & Mugil curema & 20 & 28.6 & 16.8 & 480.5 & 1 \\
\hline & Mugil gaimardianus & 2 & 14.3 & 1.7 & 24.3 & 11 \\
\hline & Mugil sp. & 3 & 14.3 & 2.5 & 35.7 & 10 \\
\hline \multirow[t]{2}{*}{ Gerreidae } & Diapterus rhombeus & 13 & 28.6 & 10.9 & 311.7 & 3 \\
\hline & Eugerres brasilianus & 3 & 28.6 & 2.5 & 71.5 & 8 \\
\hline Clupeidae & Pellona harroweri & 3 & 14.3 & 2.5 & 35.7 & 10 \\
\hline Trichiuridade & Trichiurus lepturus & 1 & 14.3 & 0.8 & 11.4 & 12 \\
\hline Gobiidae & Gobionellus oceanicus & 5 & 28.6 & 4.2 & 120.1 & 6 \\
\hline Non identified & - & 23 & 85.8 & 19.3 & - & - \\
\hline \multicolumn{7}{|l|}{ CEPHALOPODS } \\
\hline Loliginidae & Lolliguncula brevis & 8 & 28.6 & 100 & 2.860 & 1 \\
\hline
\end{tabular}


Table IV. Preys of Guiana dolphin Sotalia guianensis and franciscana Pontoporia blainvillei in Babitonga Bay, Southern Brazil, and respective values of the mean of total length and standard deviation $(\mathrm{SD})(\mathrm{cm})$ for each prey species. (...) Indicates the presence of a prey item, but that was impossible to identify; (-) Indicates the absence of the prey item.

\begin{tabular}{|c|c|c|c|c|}
\hline \multirow[t]{2}{*}{ Prey } & \multicolumn{2}{|c|}{ Number of prey measured } & \multicolumn{2}{|c|}{ Total length $\pm \mathrm{SD}(\mathrm{cm})$} \\
\hline & S. guianensis & P. blainvillei & S. guianensis & P. blainvillei \\
\hline \multicolumn{5}{|l|}{ TELEOST } \\
\hline Achirus lineatus & 2 & - & $10.2 \pm 1.1$ & - \\
\hline Citharichthys spilopterus & 9 & - & $11.3 \pm 1.7$ & - \\
\hline Citharichthys arenaceus & 1 & - & 15.8 & - \\
\hline Paralichthys isosceles & - & 2 & - & $5.6 \pm 0.03$ \\
\hline Symphurus tesselatus & 1 & - & 14.2 & - \\
\hline Cetengraulis edentulus & 5 & 21 & $10.1 \pm 1.3$ & $9.2 \pm 1.9$ \\
\hline Anchoa filifera & 1 & 6 & 8.9 & $5 \pm 0.2$ \\
\hline Lycengraulis grossidens & $\cdots$ & 9 & $\cdots$ & $1.01 \pm 0.1$ \\
\hline Larimus breviceps & $\cdots$ & - & $\ldots$ & - \\
\hline Stellifer brasiliensis & 7 & 19 & $8.5 \pm 3.1$ & $9.7 \pm 0.9$ \\
\hline Stellifer rastrifer & - & 40 & - & $10.8 \pm 1.1$ \\
\hline Cynoscion leiarchus & 2 & $\cdots$ & $9.7 \pm 0.6$ & $\cdots$ \\
\hline Conodon nobilis & $\cdots$ & - & $\cdots$ & - \\
\hline Micropogonias furnieri & 14 & 2 & $10.4 \pm 3$ & $4.1 \pm 0.05$ \\
\hline Cynoscion microlepidotus & - & $\cdots$ & - & $\ldots$ \\
\hline Isopisthus parvipinnis & - & 8 & - & $5.7 \pm 1.2$ \\
\hline Diapterus rhombeus & $\cdots$ & - & $\cdots$ & - \\
\hline Eugerres brasilianus & $\cdots$ & $\cdots$ & $\cdots$ & $\cdots$ \\
\hline Pellona harroweri & $\cdots$ & - & $\cdots$ & - \\
\hline Opisthonema oglinum & - & $\cdots$ & - & $\cdots$ \\
\hline Trichiurus lepturus & 1 & - & 110 & - \\
\hline Gobionellus oceanicus & 4 & 167 & $26.31 \pm 5.7$ & $13.29 \pm 4.5$ \\
\hline \multicolumn{5}{|l|}{ CEPHALOPODS } \\
\hline Lolliguncula brevis & 8 & 32 & $4.5 \pm 0.3$ & $5.5 \pm 0.9$ \\
\hline
\end{tabular}

was achieved by the identification of the prey species consumed by these cetaceans in the Babitonga Bay estuary. For franciscanas, our sample consisted of around $16 \%$ of the estimated population and for Guiana dolphin we analysed around $3.4 \%$ of the estimated population.

The Guiana dolphin diet exhibited higher richness than the franciscana diet. The number of preys varied along the distribution of these species in south and southeastern Atlantic (SANTOS et al., 2002; GURJÃo et al., 2003; Di Beneditto \& Siciliano, 2007; Bittar \& Di Beneditto, 2009; Daura-Jorge et al., 2011) and could be related to changes in prey availability and accessibility (DANILEvicz et al., 2002; DAURA-JoRge et al., 2011). Predation on abundant resources could characterize an opportunistic behaviour, following the definition of BEGON et al. (1996). This characteristic could lead the species to change its foraging patterns as a consequence of fish stock reductions (DANILEVICZ et al., 2002), and could represent a reduced vulnerability of the franciscanas in relation to food availability.

The three fish species with the highest IRI values in the franciscana diet ( $S$. rastrifer, G. oceanicus and C. edentulus) have a small size, occur in large schools and show a high abundance in estuaries (Almeida \& Branco, 2002; Silva et al., 2003; Andrade-Tubino et al., 2008). For the Guiana dolphins, the two fish species with highest IRI values are species of large size and high energy value (M. curema and M. furnieri) (СuRCHO et al., 2009) that show variations in abundance of adult individuals inside estuarine regions (CAStro \& Petrere, 2001; CARvalho et al., 2007).

It is not possible with our data to make conclusive analysis whether the species consume prey of different size. Literature information indicated that prey size for $S$. guianensis changes along its distribution, as recorder by PANSARD et al. (2010) (mean $13.18 \pm 8.85 \mathrm{~cm}$ ) and DAURA-Jorge et al. $(2011)($ mean $=21.4 \pm 21.2 \mathrm{~cm})$. For P. blainvillei it seems that the species preys on fishes of smaller total length (Rodriguez et al., 2002; BitTAR \& DI BeneditTo, 2009).

Lolliguncula brevis was important prey species for both cetaceans and was the only cephalopod recorded. Cephalopods were also very important in the diet of P. blainvillei in the north coast of state of Rio de Janeiro (Bittar \& Di Beneditto, 2009), but have low importance for $S$. guianensis both north and south of its distribution (PANSARD et al., 2010; DAURA-JoRGE et al., 2011). Loligo plei (Blainville, 1823) and Loligo sanpaulensis (Brakoniecki, 1984), which have been identified in franciscana and Guiana dolphin diets in other Brazilian states (Di Beneditto \& Siciliano, 2007; Bittar \& Di Beneditto, 2009), are species with a wide distribution along the coast of state of Santa Catarina (Perez, 2002). This species was also the only cephalopod registered in Guiana dolphin stomachs at North Bay, also in Santa Catarina (DAURA-Jorge et al., 2011). Only in 
the genus Lolliguncula there are cephalopod species that are highly tolerant to low salinity, common in estuaries (VeCCHIONe, 1991).

MARCUCCI \& CREMER (2003) analysed the franciscana diet from individuals recovered outside of the Babitonga Bay estuary in state of Santa Catarina. Among the prey identified, two teleost fishes and one cephalopod were different from the species identified in the individuals recovered inside the estuary: Anchoa tricolor (Spix \& Agassiz, 1829), Paralonchurus brasiliensis (Steindachner, 1875) and L. plei, respectively. These fish and cephalopod species have very coastal habits and rarely are found inside estuarine environments, indicating some local differences in the diet of the franciscana. CRemer \& SimÕes-Lopes (2008), based on information about the animals distribution, suggest that franciscanas of the Babitonga Bay are resident and remain within the bay along the whole year.

Thus, this hypothesis could have been enhanced with this information on the diet of the population. The franciscana diet in Babitonga Bay was composed only of prey that typically occurs in estuarine waters, probably indicating that these animals do not leave the bay.

Because of our small sample size, it was not possible to analyse the diet with respect to different ages, sex or seasonality. Furthermore, it is possible that our results are strongly influenced by the composition of the sample. This problem is more evident in the case of Guiana dolphin because information was obtained only from males. Variations in diet composition have been observed for the franciscana in Argentina (RodRíguez et al. 2002).

Analysing prey behaviour, we conclude that both dolphins feed at the surface and at the bottom of the water column. The majority of the prey species form large schools, and this could influence the predators' feeding behaviour. Predation on fish schools requires coordinated group behaviour to amplify individual success. The occurrence of large groups participating in feeding behaviours has been observed in Babitonga Bay for Guiana dolphins (CREMER et al., 2011) and for franciscanas (CREMER \& SimÕEs-Lopes, 2005). Additionally, flatfishes were registered in the stomachs of both franciscanas and Guiana dolphins, and fishing behaviour associated with the bottom, as described for Guiana dolphin by Rossi-SANTOS \& WEDEKIN (2006), has also been observed in the study area.

The fact that the studied species occupy a similar feeding niche in an area where they are in sympatry could be explained by the abundance of resources. Moreover, the prey species with higher importance for each of the cetacean species do not overlap, and this fact could contribute to the co-occurrence of these populations. In the Bay of Biscay, bottlenose dolphins and harbour porpoise have been observed to exhibit interference competition because they occur in mixedpredator aggregations and show a significant feeding niche overlap (Spitz et al., 2006). In Babitonga Bay, franciscana and Guiana dolphins do not form mixedpredator aggregations, although both species use the same foraging habitats (CREMER \& Simões-Lopes, 2005).

The information available about the distribution of Guiana dolphins and franciscana in Babitonga Bay, collected in the last 10 years, indicates that both cetacean populations might be resident in the Babitonga Bay estuary (CREMER \& SimÕes-Lopes, 2005, 2008; CREMER et al., 2011). All of the prey species identified occur inside the estuary, which reinforces the importance of Babitonga Bay for these populations because it represents a secure habitat against predators with the availability of food for both cetacean populations.

Acknowledgements. The authors are grateful for the help of the members of the Cetáceos da Babitonga project, who helped in animal recovery during the study years. Special thanks to Elisabeth A. L. de Souza, who helped to analyse the stomach contents. We are in debt to Roberta dos Santos, CEPSUL/ICMBio, who identified the cephalopod beaks and to André Barreto, CTTMar/UNIVALI, who provided the image analysis system for the otoliths. This work would not have been possible without the financial support provided by the Universidade da Região de Joinville through the Fundo de Apoio à Pesquisa. P. C. Simões-Lopes received financial support from $\mathrm{CNPq}$ (grant process number 304698/2006-7), and M. J. Cremer received financial support from CAPES (2003-2004) and from UNIVILLE through the Programa de Qualificação Docente.

\section{REFERENCES}

Almeida L. R. \& Branco, J. O. 2002. Aspectos biológicos de Stellifer stellifer na pesca artesanal do camarão sete-barbas, Armação do Itapocoroy, Penha, Santa Catarina, Brasil. Revista Brasileira de Zoologia 19:601-610.

Andrade-Tubino, M. F.; Ribeiro, A. L. R. \& Vianna, M. 2008. Organização espaço-temporal das ictiocenoses demersais nos ecossistemas estuarinos brasileiros: uma síntese. Oecologia Brasiliensis 12:640-661.

Barros, N. B. \& Odell, D. K. 1990. Food habits of bottlenose dolphins in the southeastern United States. In: Leatherwood, S. \& Reeves, R. R. eds. The bottlenose dolphin. San Diego, Academic Press, p.309-328.

Barros, N. B. \& Wells, R. S. 1998. Prey and feeding patterns of resident bottlenose dolphins (Tursiops truncatus) in Sarasota Bay, Florida. Journal of Mammalogy 79:1045-1059.

Bearzi, M. 2005. Dolphin sympatric ecology. Marine Biology Research 1:165-175

Begon, M.; Harper, J. L. \& Townsend, C. R. 1996. Ecology individuals, populations and communities. 3ed. Oxford, Blackwell Science. 1068p

Bittar, V. T. \& Di Beneditto, A. P. M. 2009. Diet and potential feeding overlap between Trichiurus lepturus (Osteichthyes, Perciformes) and Pontoporia blainvillei (Mammalia, Cetacea) in northern Rio de Janeiro, Brazil. Zoologia 26(2):374-378.

Borobia, M. \& Barros, N. B. 1989. Notes on the diet of marine Sotalia fluviatilis. Marine Mammal Science 5:395-399.

Bowen, W. D. \& SinifF, D. B. 1999. Distribution, population biology, and feeding ecology of marine mammals. In: REYNOLDS III, J. E. \& Rommel, S. A. eds. Biology of marine mammals. Washington, Smithsonian Institution Press, p.423-484.

CARr, T. \& Bonde, R. K. 2000. Tucuxi (Sotalia fluviatilis) occurs in Nicaragua, $800 \mathrm{~km}$ off its previously known range. Marine Mammal Science 16:447-452.

Carvalho, C. D.; Corneta, C. M. \& Uieda, V. S. 2007. Schooling behavior of Mugil curema (Perciformes: Mugilidae) in an estuary in southeastern Brazil. Neotropical Ichthyology 5:81-83.

Castro, L. A. B. \& Petrere, M. 2001. Estrutura populacional e mortalidade de Micropogonias furnieri, Macrodon ancylodon e Cynoscion jamaicensis no sudeste do Brasil, de 1982 a 1996. Boletim do Instituto de Pesca 27:61-76.

CorrêA, M. F. \& Vianna, M. S. 1992. Catálogo de Scianidae (Osteichthyes - Perciformes) do litoral do Estado do Paraná Brasil. Nerítica 7:13-41 
Cremer, M. J. \& Simões-Lopes, P. C. 2005. The occurrence of Pontoporia blainvillei (Gervais \& d'Orbigny) (Cetacea, Pontoporiidae) in an estuarine area in southern Brazil. Revista Brasileira de Zoologia 22:717-723.

2008. Distribution, abundance and density estimates of franciscanas, Pontoporia blainvillei (Cetacea: Pontoporiidae), in Babitonga bay, southern Brazil. Revista Brasileira de Zoologia 25:397-402.

Cremer, M. J.; Hardt, F. A. S.; Tonello-Júnior, A. J. \& Simões-Lopes, P. C. 2011. Distribution and status of the Guiana dolphin Sotalia guianensis (Cetacea, Delphinidae) population in Babitonga bay, Southern Brazil. Zoological Studies 50:327-337.

Crespo, E. A.; Harris, G. \& GonzÁlez, R. 1998. Group size and distributional range of the franciscana, Pontoporia blainvillei. Marine Mammal Science 14:845-849

Curcho, M. R. S. M.; Farias, L. A.; Baggio, S. R.; Fonseca, B. C.; Nascimento, S. M.; Bortoli, M. C.; Braga, E. S. \& Fávaro, D. I. T. 2009. Avaliação da concentração de mercúrio total e metilmercúrio e composição de ácidos graxos em pescado consumido em Cananéia, São Paulo, Brasil. Revista do Instituto Adolfo Lutz 68(3):442-450.

Danilewitz, D.; Rosas, F.; Bastida, R.; Marigo, J.; Muelbert, M.; Rodríguez, D.; Lailson Brito JR, J.; Ruoppolo, V.; Ramos, R.; Bassol, M.; OtT, P. H.; CAON, G.; DA Rocha, A. M.; Catão-Dias, J. L. \& SECCHI, E. R. 2002. Report on the working group on biology and ecology. Latin American Journal of Aquatic Mammals 1(1):25-42.

Daura-Jorge, F. G.; Wedekin, L. L. \& Simões-Lopes, P. C. 2011. Feeding habits of the Guiana dolphin, Sotalia guianensis (Cetacea: Delphinidae), in Norte Bay, southern Brazil. Scientia Marina 75(1):163-169.

Di Beneditto, A. P. M. \& Siciliano, S. 2007. Stomach contents of the marine tucuxi dolphin (Sotalia guianensis) from Rio de Janeiro, south-eastern Brazil. Journal of the Marine Biological Association UK 87:253-254.

Fitch, J. E. \& Brownell, R. L. 1968. Fish otoliths in cetacean stomachs and their importance in interpreting feeding habits. Journal of the Fish Research Board Canada 25:2561-2574

1971. Food habits of the franciscana Pontoporia blainvillei (Cetacea: Platanistidae) from South America. Bulletin of Marine Science 21:626-636.

Gurjão, L. M.; Furtado-Neto, M. A. A.; Santos, R. A. \& Cascon, P. 2003. Feeding habits of marine tucuxi, Sotalia fluviatilis, at Ceará State, northeastern Brazil. Latin American Journal of Aquatic Mammals 2:117-122

Lemos, P. H. B.; CorrêA, M. F. \& AbilhôA, V. 1992. Catálogo de otólitos de Gerreidae (Osteichthyes - Perciformes) no litoral do estado do Paraná, Brasil. Nerítica 7:109-117.

Lemos, P. H. B.; CorrêA, M. F. \& Pinheiro, P. C. 1995a. Catálogo de otólitos de Engraulidae (Clupeiformes - Osteichthyes) no litoral do estado do Paraná, Brasil. Nerítica 38:731-745.

1995b. Catálogo de otólitos de Clupeidae (Clupeiformes Osteichthyes) no litoral do estado do Paraná, Brasil. Nerítica 38:747-759.

Marcucci, A. \& Cremer, M. J. 2003. Estudo da ecologia alimentar de Sotalia guianensis (Cetacea, Delphinidae) e Pontoporia blainvillei (Cetacea, Pontoporiidae) na região da Baía da Babitonga, Santa Catarina, Brasil. Cadernos de Iniciação à Pesquisa 5:51-59.

Pauly, D.; Trites, A. W.; Capuli, E. \& Christensen, V. 1998. Diet composition and trophic levels of marine mammals. Journal of Marine Science 55:467-481

Pansard, K. C. A.; Gurgel, H. C. B.; Andrade, L. D. A. \& Yamamoto, M. E. 2010. Feeding ecology of the estuarine dolphin (Sotalia guianensis) on the coast of the Rio Grande do Norte, Brazil. Marine Mammal Science 27:673-687.

Perez, J. A. A. 2002. Biomass dynamics of the squid Loligo plei and the development of a small-scale seasonal fishery off Southern Brazil. Bulletin of Marine Science 71:633-651.

Pierce, G. J. \& Boyle, P. R. 1991. A review of the methods for diet analysis in piscivorous marine mammal. Oceanographic Marine Biology Annual Review 29:409-486.

Pinheiro, L. \& CREMER, M. J. 2003. Etnoecologia e captura acidental de golfinhos (Cetacea: Pontoporiidae e Delphinidae) na Baía de Babitonga, Santa Catarina. Desenvolvimento e Meio Ambiente 8:69-75.

Pinkas, L.; Oliphant, M. S. \& Iverson, I. L. K. 1971. Food habits of albacore, bluefin tuna and bonito in Californian waters. Fishery Bulletin 152:1-105.

Rodríguez, D.; Rivero, L. \& Bastida, R. 2002. Feeding ecology of the franciscana (Pontoporia blainvillei) in marine and estuarine waters of Argentina. Latin American Journal of Aquatic Mammals 1:77-94.

Rossi-Santos, M. R. \& Wedekin, L. L. 2006. Evidence of bottom contact behavior by estuarine dolphins (Sotalia guianensis) on the eastern coast of Brazil. Aquatic Mammals 32:140-144.

Santos, M. C. O.; Rosso, S.; Santos, R. A.; Lucato, S. H. B. \& Bassoi, M. 2002. Insights on small cetacean feeding habits in southeastern Brazil. Aquatic Mammals 28:38-45.

Santos, R. H. Dos \& Haimovici, M. 2001. Cephalopods in the diet of marine mammals stranded or incidentally caught along southeastern and southern Brazil (21-34 $\mathrm{S})$. Fisheries Research 52:99-112.

Siciliano, S. 1994. Review of small cetaceans and fishery interactions in coastal waters of Brazil. Report International Whaling Commission 15:241-250.

Silva, M. A.; Araújo, F. G.; Azevedo, M. C. C. \& Mendonça, P. 2003. Distribuição espacial e temporal de Cetengraulis edentulus (Cuvier) (Actinopterygii, Engraulidae) na Baía de Sepetiba, Rio de Janeiro, Brasil. Revista Brasileira de Zoologia 20:577-581.

Simões-Lopes, P. C. 1988. Ocorrência de uma população de Sotalia fluviatilis, Gervais 1853, (Cetacea, Dephinidae) no limite sul de sua distribuição, Santa Catarina, Brasil. Biotemas 1:57-62.

Spitz, J.; Rousseau, Y. \& Ridoux, V. 2006. Diet overlap between harbour porpoise and bottlenose dolphin: an argument in favour of interference competition for food? Estuarine and Coastal Shelf Sciences 70:259-270.

VeCCHIONE, M. 1991. Observations on the paralarval ecology of a euryhaline squid, Lolliguncula brevis (Cephalopoda: Loliginidae). Fishery Bulletin 89:515-521. 